\title{
I 0 I 3 Impaired left ventricular function at rest and stress in patients with severe coronary artery disease after heart transplantation detected by dobutamine stress magnetic resonance imaging
} Constanze Merten*, Sonja Refle, Stephanie Lehrke, Dirk Lossnitzer, Thomas Dengler, Hugo A Katus, Evangelos Giannitsis and Henning Steen

Address: University Hospital Heidelberg, Heidelberg, Germany

* Corresponding author

from I th Annual SCMR Scientific Sessions

Los Angeles, CA, USA. I-3 February 2008

Published: 22 October 2008

Journal of Cardiovascular Magnetic Resonance 2008, I0(SuppI I):AI38 doi:I0.II86/I532-429X-I0-SI-AI38

This abstract is available from: http://jcmr-online.com/content/I0/SI/AI38

(c) 2008 Merten et al; licensee BioMed Central Ltd.

\section{Introduction}

Transplant coronary artery disease (TCAD) importantly affects long-term survival in patients after heart transplantation (HTX). Usually annual coronary angiography is used to assess presence and severity of TCAD.

\section{Purpose}

We sought to use rest and dobutamine stress cardiac magnetic resonance imaging (DS-CMRI) as a non-invasive technique to evaluate functional impairment due to significant TCAD.

\section{Methods}

54 patients at a mean interval of 7.2 years (range 0.9 to 16.8 ys) after HTX underwent rest and DS-CMRI. According to coronary angiography results patients were divided into 3 groups $(1=$ normal coronary arteries $(C A), n=29$; $2=$ CA stenosis $<75 \%, \mathrm{n}=15 ; 3=$ significant CA stenosis $>75 \%, \mathrm{n}=10$ ).

\section{Results}

At rest, group 1 and 2 did not differ significantly regarding left ventricular (LV) function and volumes whereas group 3 showed a significantly lower LV ejection fraction (EF) $(61.6 \% \pm 7.2$ and $58.3 \% \pm 9.2$ vs. $49.3 \% \pm 12.3 ; \mathrm{p}=$ $0.002)$ and higher endsystolic volumes (ESV) $(55.3 \mathrm{ml} \pm$ $22,0$ and $62.3 \mathrm{ml} \pm 15.7$ vs. $88.6 \mathrm{ml} \pm 40.9 ; \mathrm{p}=0,004)$. Enddiastolic volumes did not differ significantly between groups. At stress, LVEF only increased significantly in group 1 and $2(61.6 \%$ vs. $70 \%$ and $58.3 \%$ vs. $69,0 \%$, respectively, $\mathrm{p}<0,01)$ compared to rest, but not in patients with severe TCAD $(49.3 \%$ vs. $52,9 \%, \mathrm{p}=\mathrm{NS})$. Similarly, ESV decreased significantly in group 1 and 2, but not in group 3. The differences between groups observed for EF and ESV at rest remained significant at maximal stimulation (cf. Figure 1).

\section{Conclusion}

Patients with severe TCAD revealed impaired LV function at rest and during dobutamine stress compared to patients without or with only mild coronary artery stenosis. Additionally, a reduced functional reserve was non-invasively detected by DS-CMRI in patients with significant TCAD. 

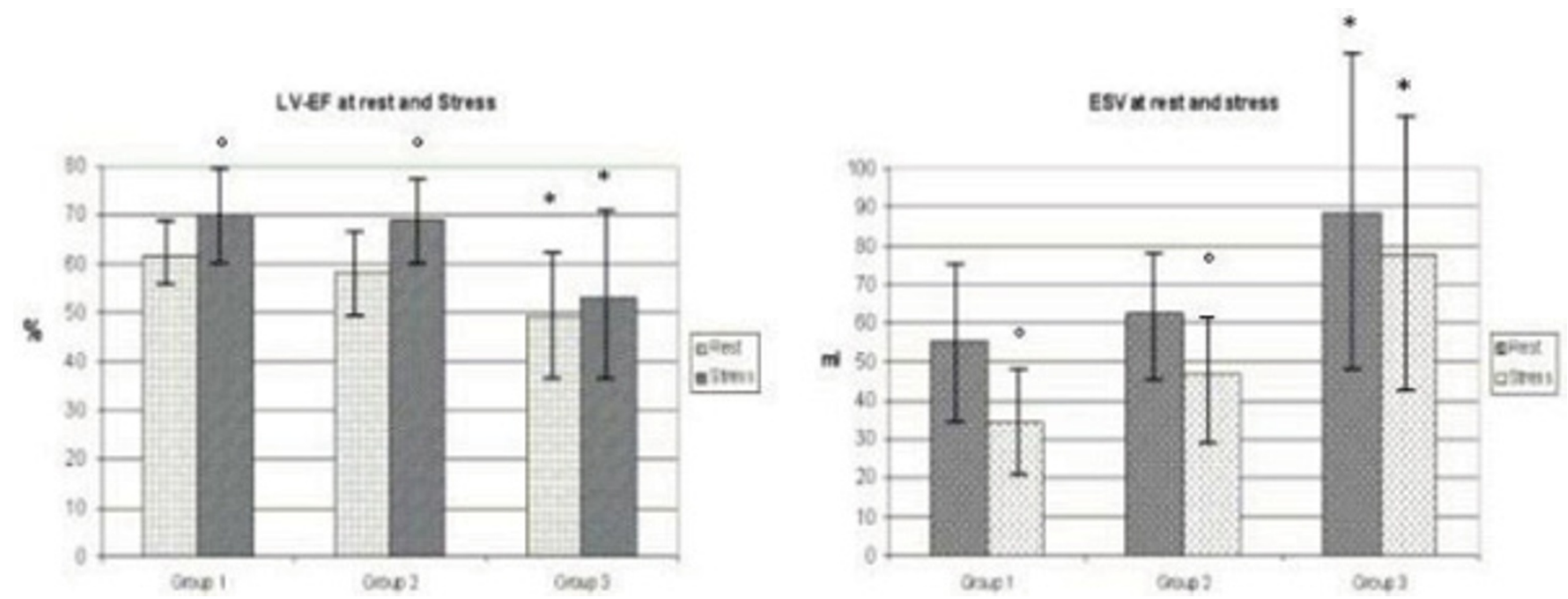

Figure I

Left ventricular ejection fraction and endsystolic volume at rest and stress. ${ }^{*} p<0.005$ vs group I and 2 ; $*_{p}<0.0$ I vs. rest.

Publish with Biomed Central and every scientist can read your work free of charge

"BioMed Central will be the most significant development for disseminating the results of biomedical research in our lifetime." Sir Paul Nurse, Cancer Research UK

Your research papers will be:

- available free of charge to the entire biomedical community

- peer reviewed and published immediately upon acceptance

- cited in PubMed and archived on PubMed Central

- yours - you keep the copyright 